\title{
Development of Blended Sapota [Manilkara achras (Mill) Fosberg] and Tamarind (Tamarindus indica L.) Jelly Cubes
}

\author{
V.T. Deokar*, K.H. Pujari and P.P. Relekar \\ Department of Post Harvest Management of Fruit, Vegetable and Flower Crops, Post \\ Graduate Institute of Post Harvest Management, Killa-Roha, Raigad, Maharashtra, India \\ *Corresponding author
}

\begin{tabular}{|l|}
\hline Ke y w o r d s \\
$\begin{array}{l}\text { Jelly, Sapota, } \\
\text { Storage, Sugar, } \\
\text { Tamarind }\end{array}$ \\
\hline Article Info \\
\hline $\begin{array}{l}\text { Accepted: } \\
\text { 07 January } 2018 \\
\text { Available Online: } \\
\text { 10 February } 2018\end{array}$ \\
\hline
\end{tabular}

A B S T R A C T

Blended sapota and tamarind jelly cube was prepared by using various proportions of sapota and tamarind fruit juices viz. 100:00, 90:10, 85:15, 80:20, 75:25 and 70:30 with 0.5 per cent level of citric acid. The blended sapota and tamarind jelly cube was evaluated for physical, chemical and sensory quality parameters during 90 days of storage to standardize the proportion of sapota and tamarind fruit juices in the blended jelly. An increasing trend in moisture, TSS, reducing sugars and total sugars and decreasing trend in titratable acidity was observed during storage period of 90 days. The jelly prepared by blending sapota and tamarind juices in the ratio 75:25 was found to be the best proportion for the preparation of blended sapota and tamarind jelly cube with highest organoleptic score for colour, flavour and overall acceptability.

\section{Introduction}

Sapota [Manilkara achras (Mill) Fosberg] is one of the most important tropical fruit belonging to the family sapotaceae. It is popularly known as chiku in India. It is one of the major fruit crops grown in India, Mexico, Guatemala and Venezuela (Kulkarni et al., 2007).

The fruit is a native of Mexico and Tropical America. The area under sapota in India was 1.21 lakh hectares, with an annual production of 14.97 lakh MT during the year 2014-2015.
The major sapota growing states in our country are Andhra Pradesh, Gujarat, Karnataka, Maharashtra and Tamil Nadu. Maharashtra produced 137.28 thousand MT sapota from 15.87 thousand hectares of area under cultivation in 2014-2015 (Anon., 2014). It is extensively grown in Gujarat, coastal Maharashtra and Karnataka. Kalipatti is an outstanding variety of sapota popularly cultivated in the Konkan region with a few other varieties like Bhuripatti, Dholadiwani and Cricket ball. Sapota fruit is highly appreciated due to its pleasant flavour, sweet taste and deep orange red colour of the pulp. 
The fruit is a good source of digestible sugar, which ranges from 15 to 20 per cent and it is virtually a treasure of minerals such as iron and calcium. The fruits have an appreciable amount of protein, fat, fiber, calcium, phosphorus, iron, carotene and vitamin $\mathrm{C}$. Edible portion of sapota contains $73.70 \mathrm{~g}$ moisture, $21.40 \mathrm{~g}$ carbohydrates, $0.70 \mathrm{~g}$ protein, $1.10 \mathrm{~g}$ fat, $28 \mathrm{mg}$ calcium, $27 \mathrm{~g}$ phosphorous, $2 \mathrm{mg}$ iron and $6 \mathrm{mg}$ ascorbic acid per $100 \mathrm{~g}$ of pulp (Sulladmath and Reddy, 1985).

It is also rich in bio-iron required for the formation of hemoglobin. It is commercially grown for the production of chickle i.e. a gum like substance obtained from the latex mainly used for the preparation of chewing gum (Balerdi et al., 2005).

Sapota is mainly valued for its sweet and delicious fruits. Sapota fruits are preferably consumed as fresh, although some studies have reported its use in preparation of jelly, jam, cheese and butter (Relekar et al., 2011). Products like sweet chutney, dried sapota pieces, sapota milk shake, nectar, blended sapota drinks, pickle, preserve and candy can also be prepared with good sensory quality (Sawant, 1989).

Even wine can be prepared from sapota fruit (Gautam and Chundawat, 1998). Processed food items viz. jelly, jam, squashes and fruit drinks are produced from sapota after blending it with other fruits (Ghade, 2013 and Pawar, 2013). They are also canned as slices (Sulladmath and Reddy, 1985).

It has been observed that when there is a bumper production of sapota, the fruit goes as waste for want of suitable preservation facilities. Thus, considering the fast increasing area under sapota cultivation, the preservation and processing technology needs to be developed in order to prevent huge post- harvest losses and regulate prices during glut period and thereby protecting the interest of the growers. Also, there are problems during rainy season, as there is glut in market during this period, it is essential to develop a new range of product, so that farmers can get an assured price for their produce all the time.

Tamarind (Tamarindus indica Linn) belonging to leguminosae family, is an important tree spices grown in the tropics. It is multipurpose tree of which almost every part finds at least some use, either nutritional or medicinal (ElSiddig et al., 2006). Tamarind is indigenous to tropical Africa, but it has been introduced and naturalized worldwide in many countries.

At present, tamarind is cultivated in 54 countries of the world, 18 in its native range and 36 other countries where it has become naturalized (Singh et al., 2007). The tamarind is mainly grown in South Africa, Afghanistan, Australia, Costa Rica, Bangladesh, Brazil, China, Malaysia, Mexico, Pakistan, Phillippines, Srilanka and India. Among these countries, Thailand, Mexico and Costa Rica are the biggest producers of tamarind (Elsidding et al., 2006).

India is the world's largest producer of tamarind. The tree mostly grows wild, although it is cultivated to a limited extent. The tamarind production in India is concentrated in the drier southern states and the produce is collected by the villagers and sold in the open market. In some parts of India, it is naturally regenerated on wastelands and forest lands. Since ancient times, India has been exporting processed tamarind pulp to western countries and more recently to the United States of America. The annual export of tamarind to the US exceeds 10,000 tonnes earning about 100 million Indian rupees. In India, the area and production of tamarind is 59 thousand ha and 188 thousand MT in the year 2014-2015, respectively (Anon., 2014). 
Nutritional composition of tamarind fruit varies considerably. The tamarind fruit contains about 55 per cent pulp and 34 per cent seeds, and shell (pod) and fiber. The fruit is a good source of calcium, phosphorous and iron, excellent source of riboflavin, thiamin and niacin, but contains small amount of Vitamin A and C. The most outstanding characteristic of tamarind is its most acidic nature with total acidity range varying from 12.2 to 23.8 per cent as tartaric acid (Morton, 1987; Chapman, 1984 and Persueglove, 1987).

The edible pulp of ripe fruits is used as flavoring agent in soups, jams, chutneys, sauces and juices. The fruit pulp is the richest natural sources of tartaric acid and is the main acidulant used in the preparation of foods in India and other Asian countries (Singh et al., 2007).

Tamarind is valued highly for its fruits, especially the pulp which is used for a wide variety of domestic and industrial purposes (Kulkarni et al., 1993) especially for food and beverages (Ajayi et al., 2006). Tamarind fruit pulp is used for seasoning, as a food component, to flavour confections, curries and sauces, and is a main component in juices and certain beverages. Tamarind fruit pulp is eaten fresh and often made into a juice, infusion or brine (El-Siddig et al., 1999; El-Siddig et al., 2006). It can also be processed into jam and sweets. The refreshing drinks are popular in many countries around the world, though there are many different recipes. In some African countries, the juice obtained from the fruit pulp is mixed with wood ash to neutralize the sour taste of the tartaric acid. However, the most common method is to add sugar to make a pleasantly acid drink.

The sapota pulp has coarse texture and lacking vitamins. To improve the quality of the sapota jelly, the sapota juice can be blended with tamarind juice for better texture and to enrich with minerals (calcium, phosphorous and iron) and vitamin B (riboflavin, thiamin and niacin). Blending of sapota juice with tamarind juice may improve the nutritional quality of the sapota and tamarind blended jelly cubes. Sapota may be used as fruit base in the preparation of blended jelly.

\section{Materials and Methods}

Fresh ripe sapota fruits were peeled and cut into small pieces with a stainless steel knife. Then, the pieces were squeezed through muslin cloth for the juice extraction. Tamarind pulp was deseeded and boiled with water in 1:8 proportion for $15 \mathrm{~min}$. The juice of both sapota and tamarind was strained by passing it through four fold muslin cloth to remove all colloidal particles and scum. The potable water was then added in both juices in 1:1 proportion. The juices of sapota (Cv. Kalipatti) and tamarind were blended in different proportions as per the treatments. About $750 \mathrm{~g}$ of blended juice of sapota and tamarind was used in each replication for the preparation of jelly. The sugar was added in 1:1 proportion in the juice. After addition of the sugar, the mixture was boiled as rapidly as possible to avoid destruction of pectin as well as to maintain the colour and flavour of the jelly. The scum was removed with the help of spoon as and when it appeared. Out of the total required sugar, $1 / 10^{\text {th }}$ part of sugar was mixed with 2 per cent pectin powder so as to dissolve the pectin easily in juice. After reaching $60^{\circ} \mathrm{B}$ TSS, pectin extract was sprinkled on mixture with continuous stirring to avoid loss of jelly forming strength of pectin. Upon reaching $65^{\circ} \mathrm{B}$ TSS, the citric acid was added @ 0.5 per cent in order to prevent sucrose crystallization in the finished product and to establish the optimum gel formation. The citric acid was added at the end of cooking for proper sugar inversion. After reaching $65^{\circ} \mathrm{B}$ TSS, the sodium benzoate was also added @ 200 ppm at the end as a 
chemical preservative. When the TSS of jelly reached to $68^{\circ} \mathrm{B}$, the blended jelly was poured hot in the cube shape moulds and allowed the jelly to set for 15 minutes in moulds. After jelly was set, the blended jelly cubes were packed in the glass bottles. Glass bottles were processed for 10 minutes in boiling water and then the jelly cubes were stored in ambient condition for further investigation.

The jelly was evaluated immediately after preparation and at an interval of 30 days up to 90 days of storage. Total soluble solids were determined using Hand refractrometer (Erma Japan, 0-32 ${ }^{0}$ Brix). Titratable acidity, reducing and total sugars were estimated by methods suggested by Ranganna (2003). The product was evaluated for their organoleptic qualities like colour, flavour and overall acceptability on a hedonic scale (Amerine et al., 1965). The observations on various parameters were recorded with three replications. The data collected were statistically analysed by the standard procedure given by Panse and Sukhatme (1985) and Amdekar (2014) using Factorial Completely Randomized Design (FCRD).

\section{Results and Discussion}

The data on the changes in moisture, TSS, acidity, reducing sugar and total sugar content of blended sapota and tamarind jelly cubes during storage is presented in Table 1 to 3 . A significant decrease was recorded for mean $\mathrm{L}^{*}$ values of jelly cubes during the storage period of 90 days. It was decreased from 52.33 to 31.77 up to 90 days of storage. Thus, it can be concluded that darkness of the colour in jelly cubes increased with increase in storage period. It might be due to change in colour of tamarind from brown to black due to phenolic and non-enzymatic browning during storage. The results in accordance with these findings were reported by Moura et al., (2011) in strawberry and guava jelly, Raut (2015) in pomegranate and sapota juice blended jelly and Gaikwad (2016) in sapota and beetroot blended jelly. Data on $a^{*}$ value for colour revealed that the redness of jelly cubes increased significantly during storage period of 90 days. At the time of preparation, mean $a^{*}$ value for colour was 9.95 which was increased significantly to 15.10 at 90 days of storage period. Similar findings for $a^{*}$ value were recorded by Moura et al., (2011) in strawberry jelly and Raut (2015) in pomegranate and sapota juice blended jelly. A continuous decreasing trend with significant differences was observed in mean $b^{*}$ value for colour during storage. It was 36.69 at the time of preparation which decreased to 15.17 at 90 days of storage. The observation in accordance with this finding was recorded by Gaikwad (2016) in sapota and beetroot blended jelly for $b^{*}$ value of colour.

Moisture content of jelly cubes changed significantly during 90 days of storage period. Maximum mean value for moisture content was observed at 90 days of storage period which was 30.57 per cent. Minimum mean value for the moisture content was observed 24.85 per cent at the time of preparation. The significant increase was observed in the moisture content of jelly cubes from 24.85 to 30.57 per cent during 0 to 90 days of storage periods. This effect was related with the increase in water activity and temperature during 90 days of storage period. Similar trends were reported by Relekar et al., (2011) in sapota jelly, and Raut (2015) in pomegranate and sapota juice blended jelly. The observations recorded on the total soluble solid contents of jelly during storage period were significantly different and showing increasing trend. The total soluble solid contents of the blended sapota tamarind jelly cubes range from $69.55{ }^{0} \mathrm{~B}$ to $70.45{ }^{0} \mathrm{~B}$ during 90 days of storage. The increasing trend in the total soluble solid content might be due to degradation or hydrolysis of polysaccharides 
like starch and pectin substances into soluble or simpler substances during 90 days of the storage. Relekar et al., (2011) observed that TSS level of sapota jelly increased significantly by the end of six months of storage period. Singh and Chandra (2012) also noticed an increase in the total soluble solid contents of mixed fruit guava and carrot jelly during 90 days of storage. Significant differences were recorded for titratable acidity of blended sapota and tamarind jelly cubes during 90 days of storage. A linear decline in the mean values of titratable acidity of blended sapota and tamarind jelly cubes was noticed from 0.65 per cent initially to 0.55 per cent after 90 days of storage and results were statistically significant.

This decrease might be due to acid hydrolysis of polysaccharides and non-reducing sugars to their simpler components where the acid is utilized for converting them to hexose sugars or complexes in the presence of metal ions (Archana and Laxman, 2015). Tomar et al., (1988) observed a decreasing trend in the titratable acidity during three months of storage period in diabetic jelly prepared from guava and papaya extracts. Raut (2015) also found a decreasing trend for titratable acidity in pomegranate and sapota juices blended jelly during three months of storage. Significant difference was observed in the mean values of reducing sugars content of blended sapota and tamarind jelly cubes during 90 days of storage period. Lowest mean value for reducing sugars content $(20.94 \%)$ was observed at the time of preparation, while highest mean value for reducing sugars content $(35.34 \%)$ was recorded at 90 days of storage. Thus, a significant increase in reducing sugar content of the blended jelly was found throughout the storage period of 90 days. This might be due to inversion of non-reducing sugars to reducing sugars after acid hydrolysis of polysaccharides. Tomar et al., (1988) recorded an increase in reducing sugar content of diabetic jelly during three months of storage period. Similar trend of increase in reducing sugar content of sapota jelly was observed by Relekar et al., (2011) and Gaikwad (2016) in sapota and beetroot blended jelly. The total sugar content of the blended jelly increased significantly from 47.24 per cent initially to 58.64 per cent after a storage period of 90 days at ambient conditions. The increase in total sugar content might be due to the acid hydrolysis of polysaccharide in soluble or simple sugars. Masoodi et al., (2005) reported similar results for total sugar content during storage in guava jelly. The identical increasing trend in total sugar content was also recorded in sapota jelly by Relekar et al., (2011).

\section{Treatment details}

\begin{tabular}{|l|c|}
\hline Treatments & Proportion of sapota and tamarind juice \\
\hline $\mathrm{T}_{1}$ & $100: 00$ \\
\hline $\mathrm{T}_{2}$ & $90: 10$ \\
\hline $\mathrm{T}_{3}$ & $85: 15$ \\
\hline $\mathrm{T}_{4}$ & $80: 20$ \\
\hline $\mathrm{T}_{5}$ & $75: 25$ \\
\hline $\mathrm{T}_{6}$ & $70: 30$ \\
\hline
\end{tabular}


Table.1 Change in physical parameters of blended sapota and tamarind jelly cubes during storage

\begin{tabular}{|c|c|c|c|c|c|c|c|c|c|c|c|c|c|c|c|}
\hline \multirow{2}{*}{$\begin{array}{c}\text { Treatments } \\
\begin{array}{c}\text { Storage } \\
\text { (days) }\end{array}\end{array}$} & \multicolumn{5}{|c|}{$\mathbf{L}^{*}$ value for colour } & \multicolumn{5}{|c|}{$a^{*}$ value of colour } & \multicolumn{5}{|c|}{ b* value of colour } \\
\hline & $\mathbf{0}$ & 30 & 60 & 90 & Mean & $\mathbf{0}$ & 30 & 60 & 90 & Mean & $\mathbf{0}$ & 30 & 60 & 90 & Mean \\
\hline $\mathbf{T 1}$ & 52.94 & 38.79 & 35.94 & 34.65 & 40.58 & 9.21 & 12.59 & 13.81 & 14.09 & 12.42 & 37.83 & 25.67 & 23.91 & 17.41 & 26.20 \\
\hline $\mathrm{T} 2$ & 52.68 & 36.88 & 33.82 & 32.53 & 38.98 & 9.35 & 12.60 & 14.26 & 14.87 & 12.77 & 37.30 & 21.96 & 18.92 & 15.51 & 23.42 \\
\hline T3 & 52.36 & 36.29 & 33.61 & 30.73 & 38.25 & 9.98 & 12.62 & 14.43 & 15.48 & 13.13 & 36.46 & 19.88 & 15.98 & 15.43 & 21.94 \\
\hline $\mathrm{T} 4$ & 51.83 & 35.40 & 32.82 & 30.60 & 37.66 & 10.14 & 13.41 & 14.72 & 15.49 & 13.44 & 36.42 & 19.00 & 15.77 & 13.82 & 21.25 \\
\hline T5 & 51.83 & 35.35 & 31.52 & 30.34 & 37.26 & 11.09 & 14.12 & 14.75 & 15.59 & 13.89 & 35.46 & 18.84 & 15.54 & 13.67 & 20.88 \\
\hline T6 & 51.12 & 34.26 & 31.46 & 30.29 & 36.78 & 12.23 & 14.58 & 14.89 & 15.61 & 14.33 & 35.13 & 15.11 & 13.80 & 13.20 & 19.31 \\
\hline Mean & 52.33 & 36.54 & 33.54 & 31.77 & & 9.95 & 13.07 & 14.39 & 15.10 & & 36.69 & 21.07 & 18.03 & 15.17 & \\
\hline \multirow[t]{3}{*}{ S.Em \pm} & \multicolumn{2}{|c|}{ Treatment } & \multicolumn{3}{|c|}{0.53} & \multicolumn{5}{|c|}{0.29} & \multicolumn{5}{|c|}{0.62} \\
\hline & \multicolumn{2}{|c|}{ Storage } & \multicolumn{3}{|c|}{0.43} & \multicolumn{5}{|c|}{0.23} & \multicolumn{5}{|c|}{0.51} \\
\hline & \multicolumn{2}{|c|}{ Interaction } & \multicolumn{3}{|c|}{1.06} & \multicolumn{5}{|c|}{0.58} & \multicolumn{5}{|c|}{1.25} \\
\hline \multirow[t]{3}{*}{$\mathrm{CD}$ at $5 \%$} & \multicolumn{2}{|c|}{ Treatment } & \multicolumn{3}{|c|}{1.51} & \multicolumn{5}{|c|}{0.82} & \multicolumn{5}{|c|}{1.78} \\
\hline & \multicolumn{2}{|c|}{ Storage } & \multicolumn{3}{|c|}{1.23} & \multicolumn{5}{|c|}{0.67} & \multicolumn{5}{|c|}{1.46} \\
\hline & \multicolumn{2}{|c|}{ Interaction } & \multicolumn{3}{|c|}{ NS } & \multicolumn{5}{|c|}{ NS } & \multicolumn{5}{|c|}{ NS } \\
\hline
\end{tabular}




\section{Int.J.Curr.Microbiol.App.Sci (2018) 7(2): 456-467}

Table.2 Change in Physico-chemical parameters of blended sapota and tamarind jelly cubes during storage

\begin{tabular}{|c|c|c|c|c|c|c|c|c|c|c|c|c|c|c|c|c|c|c|c|c|c|c|c|c|c|}
\hline \multirow{2}{*}{$\begin{array}{c}\text { Treatments } \\
\begin{array}{c}\text { Storage } \\
\text { (days) }\end{array}\end{array}$} & \multicolumn{5}{|c|}{ Moisture } & \multicolumn{5}{|c|}{ TSS } & \multicolumn{5}{|c|}{ Acidity } & \multicolumn{5}{|c|}{ Reducing sugars } & \multicolumn{5}{|c|}{ Total sugars } \\
\hline & $\mathbf{0}$ & 30 & 60 & 90 & Mean & $\mathbf{0}$ & 30 & 60 & 90 & Mean & o & 30 & 60 & 90 & Mean & $\mathbf{0}$ & 30 & 60 & 90 & Mean & o & 30 & 60 & 90 & Mean \\
\hline $\mathbf{T 1}$ & 23.03 & 25.69 & 28.20 & 29.48 & 26.60 & 69.87 & 70.27 & 70.53 & 70.67 & 70.33 & 0.51 & 0.48 & 0.44 & 0.41 & 0.46 & 17.99 & 22.53 & 28.00 & 31.80 & 25.08 & 50.68 & 55.30 & 59.33 & 63.05 & 57.09 \\
\hline $\mathbf{T} 2$ & 24.92 & 26.36 & 28.32 & 30.08 & 27.42 & 69.80 & 70.13 & 70.33 & 70.47 & 70.18 & 0.60 & 0.55 & 0.55 & 0.54 & 0.56 & 18.73 & 25.92 & 30.30 & 34.19 & 27.29 & 48.48 & 52.01 & 56.04 & 59.54 & 54.02 \\
\hline $\mathbf{T 3}$ & 25.17 & 27.16 & 29.11 & 30.72 & 28.04 & 69.60 & 69.93 & 70.20 & 70.40 & 70.03 & 0.68 & 0.65 & 0.62 & 0.57 & 0.63 & 20.72 & 26.96 & 32.16 & 35.27 & 28.78 & 47.21 & 51.74 & 53.73 & 58.20 & 52.72 \\
\hline $\mathrm{T} 4$ & 25.51 & 27.54 & 29.36 & 31.03 & 28.36 & 69.33 & 69.87 & 70.20 & 70.37 & 69.94 & 0.71 & 0.68 & 0.68 & 0.60 & 0.67 & 21.90 & 27.42 & 33.16 & 36.38 & 29.72 & 45.46 & 51.14 & 53.53 & 58.20 & 52.08 \\
\hline $\mathrm{T} 5$ & 25.60 & 28.08 & 29.56 & 31.52 & 28.69 & 69.17 & 69.60 & 70.07 & 70.37 & 69.80 & 0.77 & 0.74 & 0.72 & 0.64 & 0.72 & 25.35 & 30.47 & 35.43 & 39.08 & 32.58 & 44.37 & 47.42 & 50.90 & 54.20 & 49.22 \\
\hline T6 & 26.70 & 28.29 & 29.78 & 31.82 & 29.15 & 68.87 & 69.40 & 69.93 & 70.33 & 69.63 & 0.80 & 0.79 & 0.75 & 0.72 & 0.77 & 28.86 & 33.25 & 37.06 & 40.59 & 34.94 & 44.05 & 47.42 & 50.59 & 53.08 & 48.59 \\
\hline Mean & 24.85 & 26.97 & 28.91 & 30.57 & & 69.55 & 69.96 & 70.27 & 70.45 & & 0.65 & 0.62 & 0.60 & 0.55 & & 20.94 & 26.66 & 31.81 & 35.34 & & 47.24 & 51.52 & 54.71 & 58.64 & \\
\hline \multirow[t]{3}{*}{ S.Em \pm} & \multicolumn{2}{|c|}{ Treatment } & \multicolumn{3}{|c|}{0.42} & \multicolumn{5}{|c|}{0.16} & \multicolumn{5}{|c|}{0.0033} & \multicolumn{5}{|c|}{0.57} & \multicolumn{5}{|c|}{0.74} \\
\hline & \multicolumn{2}{|c|}{ Storage } & \multicolumn{3}{|c|}{0.34} & \multicolumn{5}{|c|}{0.13} & \multicolumn{5}{|c|}{0.0027} & \multicolumn{5}{|c|}{0.47} & \multicolumn{5}{|c|}{0.61} \\
\hline & \multicolumn{2}{|c|}{ Interaction } & \multicolumn{3}{|c|}{0.84} & \multicolumn{5}{|c|}{0.32} & \multicolumn{5}{|c|}{0.0067} & \multicolumn{5}{|c|}{1.14} & \multicolumn{5}{|c|}{1.48} \\
\hline \multirow[t]{3}{*}{ CD at $5 \%$} & \multicolumn{2}{|c|}{ Treatment } & \multicolumn{3}{|c|}{1.20} & \multicolumn{5}{|c|}{0.45} & & & 0.010 & & & & & 1.63 & & & & & 2.12 & & \\
\hline & Sto & & & 0.98 & & & & 0.37 & & & & & 0.008 & & & & & 1.33 & & & & & 1.73 & & \\
\hline & Inter & ction & & NS & & & & NS & & & & & 0.019 & & & & & NS & & & & & NS & & \\
\hline
\end{tabular}


Table.3 Change in sensory parameters of blended sapota and tamarind jelly cubes during storage

\begin{tabular}{|c|c|c|c|c|c|c|c|c|c|c|c|c|c|c|c|c|c|c|c|c|}
\hline Treatments & \multicolumn{5}{|c|}{ Colour } & \multicolumn{5}{|c|}{ Flavour } & \multicolumn{5}{|c|}{ Texture } & \multicolumn{5}{|c|}{ Overall acceptablty } \\
\hline $\begin{array}{c}\text { Storage } \\
\text { (days) }\end{array}$ & $\mathbf{0}$ & 30 & 60 & 90 & Mean & $\mathbf{0}$ & 30 & 60 & 90 & Mean & $\mathbf{0}$ & 30 & 60 & 90 & Mean & $\mathbf{0}$ & 30 & 60 & 90 & Mean \\
\hline T1 & 7.50 & 7.47 & 7.33 & 7.13 & 7.36 & 7.43 & 7.40 & 7.23 & 6.67 & 7.18 & 7.87 & 7.83 & 7.80 & 7.60 & 7.78 & 7.60 & 7.57 & 7.45 & 7.14 & 7.44 \\
\hline T2 & 7.82 & 7.75 & 7.40 & 7.17 & 7.53 & 7.50 & 7.37 & 7.33 & 6.73 & 7.23 & 7.90 & 7.87 & 7.83 & 7.63 & 7.81 & 7.74 & 7.66 & 7.52 & 7.17 & 7.52 \\
\hline T3 & 7.93 & 7.80 & 7.47 & 7.20 & 7.60 & 7.60 & 7.53 & 7.37 & 7.10 & 7.40 & 7.93 & 7.90 & 7.87 & 7.67 & 7.84 & 7.82 & 7.74 & 7.56 & 7.32 & 7.61 \\
\hline $\mathrm{T} 4$ & 7.97 & 7.90 & 7.53 & 7.30 & 7.68 & 7.73 & 7.63 & 7.40 & 7.17 & 7.48 & 7.97 & 7.93 & 7.87 & 7.70 & 7.87 & 7.89 & 7.82 & 7.60 & 7.39 & 7.67 \\
\hline T5 & 8.00 & 7.97 & 7.57 & 7.33 & 7.72 & 8.07 & 7.80 & 7.57 & 7.40 & 7.71 & 8.00 & 7.97 & 7.90 & 7.80 & 7.92 & 8.02 & 7.91 & 7.68 & 7.51 & 7.78 \\
\hline T6 & 7.87 & 7.73 & 7.43 & 7.23 & 7.57 & 7.60 & 7.47 & 7.00 & 5.83 & 7.01 & 7.97 & 7.90 & 7.83 & 7.67 & 7.84 & 7.81 & 7.70 & 7.42 & 6.91 & 7.46 \\
\hline Mean & 7.84 & 7.78 & 7.46 & 7.23 & & 7.67 & 7.55 & 7.38 & 7.01 & & 7.93 & 7.90 & 7.85 & 7.68 & & 7.81 & 7.74 & 7.56 & 7.30 & \\
\hline \multirow[t]{3}{*}{ S.Em \pm} & \multicolumn{2}{|c|}{ Treatment } & \multicolumn{3}{|c|}{0.07} & \multicolumn{5}{|c|}{0.12} & \multicolumn{5}{|c|}{0.07} & \multicolumn{5}{|c|}{0.09} \\
\hline & \multicolumn{2}{|c|}{ Storage } & \multicolumn{3}{|c|}{0.06} & \multicolumn{5}{|c|}{0.10} & \multicolumn{5}{|c|}{0.06} & \multicolumn{5}{|c|}{0.22} \\
\hline & \multicolumn{2}{|c|}{ Interaction } & \multicolumn{3}{|c|}{0.14} & \multicolumn{5}{|c|}{0.23} & \multicolumn{5}{|c|}{0.14} & \multicolumn{5}{|c|}{0.19} \\
\hline \multirow[t]{3}{*}{ CD at $5 \%$} & \multicolumn{2}{|c|}{ Treatment } & \multicolumn{3}{|c|}{0.20} & \multicolumn{5}{|c|}{0.33} & \multicolumn{5}{|c|}{ NS } & \multicolumn{5}{|c|}{ NS } \\
\hline & \multirow{2}{*}{\multicolumn{2}{|c|}{ Storage }} & \multicolumn{3}{|c|}{0.16} & \multicolumn{5}{|c|}{0.27} & \multicolumn{5}{|c|}{0.16} & \multicolumn{5}{|c|}{0.08} \\
\hline & & & & NS & & & & NS & & & & & NS & & & & & NS & & \\
\hline
\end{tabular}




\section{Flow Chart-I}

\section{Extraction of sapota juice}

\section{Selection of sapota fruits}

Washing and cleaning of sapota

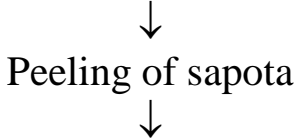

Cutting of peeled sapota into small pieces

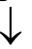

Squeezing the pieces through muslin cloth for juice extraction

Extraction of tamarind juice

Selection of deseeded tamarind pulp

Cleaning of tamarind

$\downarrow$

Boiling with water in 1:8 proportion for 15 minutes

$\downarrow$

Extraction of juice through muslin cloth

\section{Flow Sheet-II}

Preparation of blended sapota and tamarind jelly cubes

Selection of sapota and tamarind

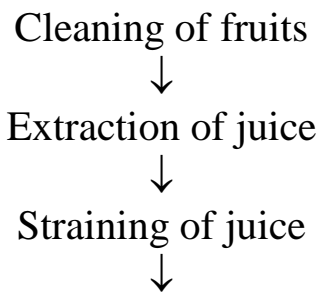

Blending of juices in different proportions as per the treatments<smiles>[AlH2]</smiles>

Addition of water in juice in 1:1 proportion

Addition of sugar in 1:1 proportion

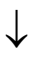

Heating the mixture upto $60^{\circ} \mathrm{B}$ TSS level

Addition of pectin@2\% 


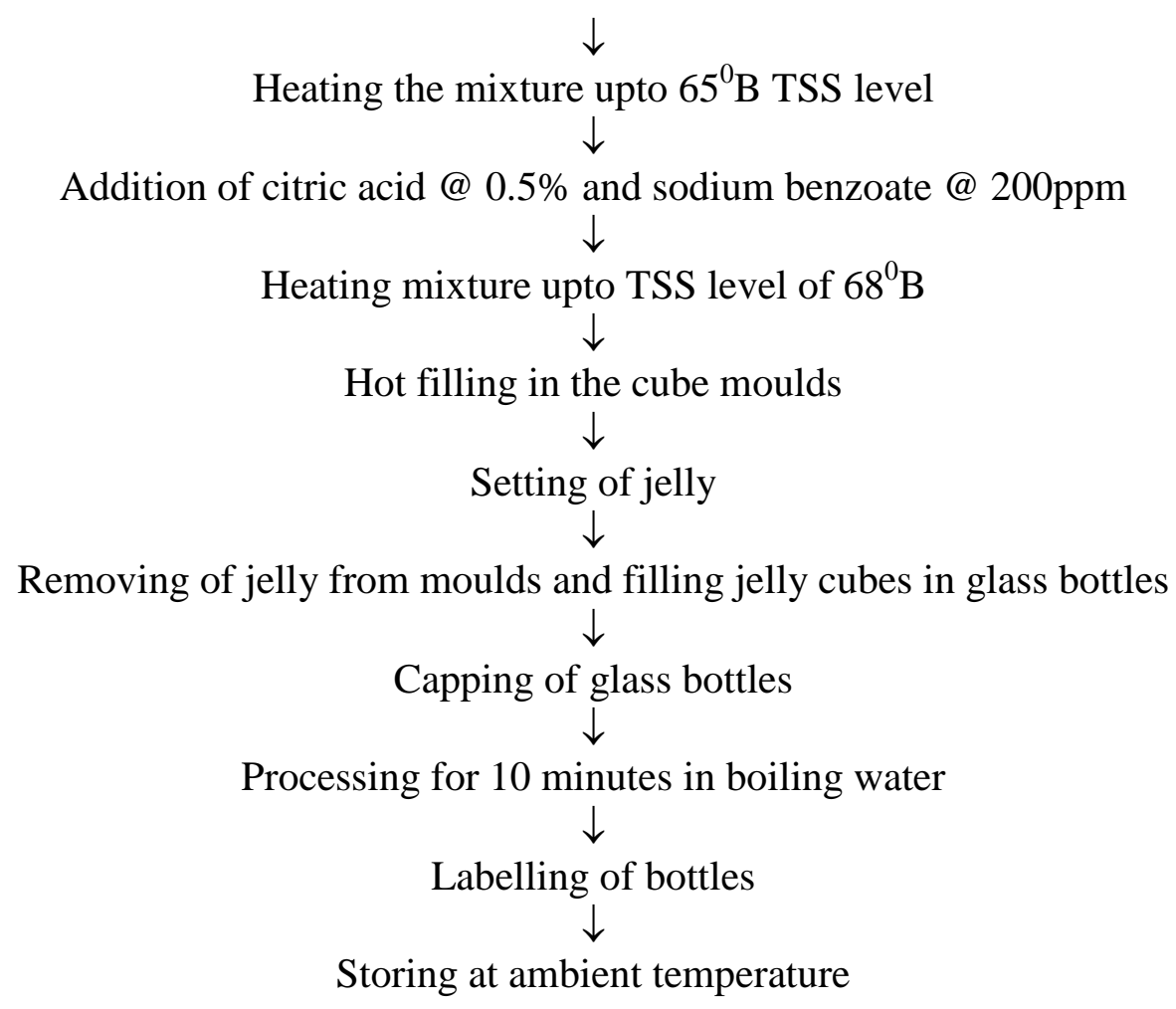

The mean sensory score for colour varied significantly during storage period of 90 days. It was highest (7.84) at the time of preparation and lowest (7.23) at 90 days of storage. It was revealed from the data that the likeness for colour of jelly decreased during storage period of 90 days. It might be due to the darkening of the jelly due to browning reactions during storage. Similar trend of decrease in sensory score for colour was observed by Raut (2015) in pomegranate and sapota juice blended jelly.

As regards storage, the mean score for flavour of the blended jelly was decreased significantly during 90 days of storage. It was maximum (7.67) at the time of preparation which decreased to 7.01 at 90 days of storage period. This indicates that as the storage period increased the flavour of blended jelly cubes declined. Singh and Chandra (2012) recorded similar results for flavour of guavacarrot jelly. The statistical analysis of sensory score for texture of blended jelly cubes reveals that there was a significant difference in mean score for texture during 90 days of storage period. The mean score for texture of the blended jelly was decreased significantly with increase in the storage period. Maximum mean score for texture (7.93) was obtained at the time of preparation which was decreased to (7.68) at 90 days of storage period. This indicates that as the storage period prolonged the texture of the blended sapota and tamarind jelly cube declined. Singh and Chandra (2012) recorded similar trend for sensory score for texture of guava and carrot jelly. Significant differences were observed in the mean sensory score for overall acceptability of blended sapota and tamarind jelly cubes during at 90 days of storage period. The mean score for overall acceptability of the blended jelly was decreased significantly with increase in the storage period. Maximum mean score for overall acceptability was (7.81) obtained at the time of preparation which was decreased to (7.30) at 90 days of storage period. Singh and Chandra (2012) recorded similar trend for sensory score for overall acceptability of guava and carrot jelly. 
It was observed from the data that the blended sapota and tamarind jelly cubes irrespective of ratios were acceptable during three months of storage at ambient conditions. Blending of sapota and tamarind improved physical, chemical and sensory quality characteristics like colour, flavour, etc. of the jelly.

The sensory evaluation of jelly revealed that the colour, flavour and firmness of the jelly retained after 90 days of storage period and the jelly was acceptable even after 90 days of storage at ambient conditions. Blending of sapota with tamarind improved colour and flavour of the blended jelly. Based on the organoleptic evaluation and economics of the jelly, it is concluded that the blended sapota and tamarind jelly cubes could be prepared successfully by blending sapota and tamarind juice in the ratio of $\mathrm{T}_{5}$ [sapota $(75 \%)$ : tamarind (25\%)].

\section{References}

Ajayi I. A., Oderinde, R. A., Kajogbola, D. O. and Uponi, J. I. 2006. Oil Content and fatty acid composition of some underutilized legumes from Nigeria. Food chemistry, 99: 115-120.

Amdekar, S. J. 2014. In: Statistical Method for Agricultural and Biological Sciences. Narosa Publishing House Private Limited. New Delhi.

Amerine, M. A., Pangborn, R. M. and Rosseler, E. B. 1965. In: Principles of sensory evaluation of foods. Academic press. New York, pp: 350-376.

Anonymous, 2014. A report of Indian horticulture database published by National Horticulture Board (NHB), Gurgaon.

Archana, P. and Laxman, K. 2015. Studies on preparation and storage of tamarind squash. Journal of Spices and Aromatic Crops. 24 (1): 37-42.

Balerdi, C. F., Crane, J. H. and Maguire, I.,
2005. Sapodilla growing in the Florida home landscape. University of Florida, IFAS Extension. pp: 10.

Chapman, K. R. 1984. Tamarind in tropical tree fruits for Australia. Compiled by P.E. page. Queens and Department of parimary industries. Information series Q 183018, Brisbane: 83-86.

EI-sidding. K., Gunasena, H. P. M., Prasa, B. A., Pushapakuma, D. K. N. G., Ramana, K. V. R., Vijayanand. P., Williams, J. T. 2006. Tamarind-Tamarindus indica L. Fruits for the future. Southampton centre for Underutilized crops, Southampton, UK, pp: 188.

El-Siddig, K., Ebert, G. and Ludders, P. 1999. Tamarindus indica L. A review on a multipurpose tree with promising future in the Sudun. Journal of applied Botany, 73: 5-6.

Gaikwad, S. U. 2016. Studies on preparation of sapota (Manilkara achras (Mill.) Fosberg): beetroot (Beta vulgaris) blended jelly.M.Sc. (Post-harvest management) Thesis, submitted to the Post Graduate Institute of Post-Harvest Management, Killa-Roha, Dist-Raigad, Maharashtra (India).

Gautam, S. K. and Chundawat B. S. 1998. Standardization of technology of sapota wine making. Indian Food Packer, 52(1): 17-21.

Ghade, P. P. 2013. Studies on sapota: papaya blended jelly. M.Sc. (Post-harvest management) Thesis, submitted to the Post Graduate Institute of Post-Harvest Management, Killa-Roha, Dist. Raigad, Maharashtra (India).

Kulkarni, A. P., Policegoudra, R. S., and Aradhya, S. M. 2007. Chemical composition and antioxidant activity of sapota (Achras sapota linn.) fruit.Journal of Food Biochemistry 31: 399-414.

Kulkarni, R. S., Gangaprasad, S. and Swamy, G. S. K. 1993. Tamarind: Economically 
an important minor forest product. Minor Forest Products News, 3(3): 6.

Masoodi, A. A., Sapra, V. and Bakshi, P. 2005. Use of tomato and carrot as biocolourants in guava jelly. Indian $F d$. Packer, 59: 87-90.

Morton, J. 1987. Tamarind. In: Fruits of warm climates, Morton, J.F. (ed.). Miami, USA, pp: 115-121.

Moura, S. C. S. R., Prat, P., Vissotto, F. Z., Rita, C. S. C. O. and Marina, S. R. 2011. Colour degradation kinetics in low-calorie strawberry and guava jellies. Cienc. Tecnol. Aliment, Campinas, 31(3): 758-764.

Panase, V. G. and Sukhatme, P. V. 1985. In: Statistical methods for Agricultural workers, Indian Council of Agriculture Research, New Delhi.

Pawar, V. C. 2013. Studies on preparation of blended jam of sapota: papaya. M.Sc. (Post-harvest Management) Thesis, submitted to the Post Graduate Institute of Post-Harvest Management, KillaRoha, Dist. Raigad, Maharashtra (India).

Purseglove, J.W. 1987. Tropical crops, Dicotyledons, Longman science and technology: 204-206.

Ranganna, S. 2003. Handbook of analysis and quality control for fruits and vegetable products. Tata McGraw-Hill Publishing
Company Limited. New Delhi.

Raut, P. S., 2015. Studies on preparation of pomegranate (Punica granatum L.): sapota (Manilkara achras (Mill.) Fosberg) blended jelly. M.Sc. (Postharvest management) thesis submitted to the Post Graduate Institute of PostHarvest Management, Killa-Roha, Dist. Raigad, Maharashtra (India).

Relekar, P. P., Naik, A. G. and Padhiar, B. V. 2011. Qualitative changes in value added products of sapota $\mathrm{Cv}$. kalipatti during storage. Indian journal of horticulture, 68(3): 431-418.

Singh, D., Lobsang Wagchu and Surendra Kumar Moond 2007. Department of Post-Harvest Technology, Maharanapratap university of Agriculture and Technology Jhalawar, Rajsthan, India, Natural product Radiance, 6(4): 315-312.

Singh, J. and Chandra, S. 2012. Preparation and evaluation of guava-carrot jelly. Intl. J. of Food Ferment. Technol., 2(2): 197-200.

Sulladmath, K. S. and Reddy, N. 1985. In: Fruits: Tropical and sub-tropical, pp: 565-591.

Tomar, M. C., Srivastava, R. K. and Bisht, N. S. 1988. Studies on the preparation and the effect of diabetic jelly on blood sugar. Indian Fd. Packer, 40: 10-14.

\section{How to cite this article:}

Deokar, V.T., K.H. Pujari and Relekar, P.P. 2018. Development of Blended Sapota [Manilkara achras (Mill) Fosberg] and Tamarind (Tamarindus indica L.) Jelly Cubes. Int.J.Curr.Microbiol.App.Sci. 7(02): 456-467. doi: https://doi.org/10.20546/ijcmas.2018.702.057 